NOTE

\title{
Influence of Membrane-Forming Surfactants on the Conformational Stability of Albumins and Polypeptides
}

\author{
Seiji ShINKAI,* Yumiko KusAno, and Osamu ManABE \\ Department of Industrial Chemistry, Faculty of Engineering, \\ Nagasaki University, Nagasaki 852, Japan. \\ Naotoshi NAKASHIMA and Toyoki KUNITAKE \\ Department of Organic Synthesis, Faculty of Engineering, \\ Kyushu University, Fukuoka 812, Japan.
}

(Received January 23, 1981)

\begin{abstract}
KEY WORDS Surfactant Micelle / Membrane-Forming Surfactant / Albumin / Denaturation / Conformation of Poly(amino acid) / Helix-Coil Transition /
\end{abstract}

Previous studies have shown that membranebound proteins as well as globular proteins bind ionic and nonionic surfactant molecules not only at concentrations above the critical micelle concentration (CMC) but also from monomeric solutions of surfactants. ${ }^{1}$ The aggregation phenomenon leads to a significant conformational change in protein molecules and is regarded as a suitable model system for the interaction between biomembranes and membrane-bound proteins. It has been also established that the helix-coil transition of some poly(amino acid)s is affected by added surfactants. ${ }^{2-4}$ This may be regarded as a more simplified model system of the protein-membrane interaction. Recently, Kunitake ${ }^{5}$ developed a new class of surfactants which form the membranous aggregates in aqueous solution. The aggregates of new surfactants are clearly distinguished from those of conventional micelle-forming surfactants in that they form the "stable" structure by the sonication treatment in contrast to micelle-forming surfactants which form no "stable" structure. ${ }^{6}$ It occurred to us that mode of interaction of proteins and poly(amino acid)s with membrane-forming surfactants may be

\footnotetext{
* To whom correspondence should be addressed.
}

quite different from that with micelle-forming surfactants. The use of membrane-forming surfactants may provide more useful information on the interaction of biomembranes and membrane-bound proteins.

In this paper, we report the influence of micelleforming and membrane-forming surfactants on the conformations of serum albumins (human and bovine: HSA and BSA, respectively), poly(L-glutamic acid) (PLGA), and poly(L-lysine) (PLL). The structure of surfactants is illustrated along below with their abbreviations.

SDS: $\mathrm{CH}_{3}\left(\mathrm{CH}_{2}\right)_{11} \mathrm{OSO}_{3} \mathrm{Na}$

CTAB: $\mathrm{CH}_{3}\left(\mathrm{CH}_{2}\right)_{15} \mathrm{~N}^{+}\left(\mathrm{CH}_{3}\right)_{3} \mathrm{Br}^{-}$

Brij-35: $\mathrm{CH}_{3}\left(\mathrm{CH}_{2}\right)_{11}\left(\mathrm{OCH}_{2} \mathrm{CH}_{2}\right)_{23} \mathrm{OH}$

$$
\begin{aligned}
2 \mathrm{C}_{10} \mathrm{SO}_{3} \mathrm{Na}: & \mathrm{CH}_{3}\left(\mathrm{CH}_{2}\right)_{9} \mathrm{OCOCH}_{2} \\
& \mathrm{CH}_{3}\left(\mathrm{CH}_{2}\right)_{9} \mathrm{OCOCHSO}_{3} \mathrm{Na}
\end{aligned}
$$

$$
\begin{array}{ll}
2 \mathrm{C}_{12} \mathrm{~N} 2 \mathrm{C}: & \stackrel{\mathrm{CH}_{3}\left(\mathrm{CH}_{2}\right)_{11}}{\mathrm{CH}_{3}\left(\mathrm{CH}_{2}\right)_{11}}, \stackrel{+}{\mathrm{N}} \backslash \underset{\mathrm{CH}_{3}}{\mathrm{CH}_{3} \mathrm{Br}^{-}} \\
2 \mathrm{C}_{12} 28 \mathrm{G}: & \\
\quad \mathrm{CH}_{3}\left(\mathrm{CH}_{2}\right)_{11} \mathrm{OCH}_{2} \backslash \mathrm{CH}\left(\mathrm{OCH}_{2} \mathrm{CH}_{2}\right)_{28} \mathrm{OH} \\
\mathrm{CH}_{3}\left(\mathrm{CH}_{2}\right)_{11} \mathrm{OCH}_{2}
\end{array}
$$




\section{EXPERIMENTAL}

SDS, CTAB, and Brij-35 were purchased from Wako-Pure Chemical Industries and used without further purification. The preparative methods of $2 \mathrm{C}_{10} \mathrm{SO}_{3} \mathrm{Na}, 2 \mathrm{C}_{12} \mathrm{~N} 2 \mathrm{C}$, and $2 \mathrm{C}_{12} 30 \mathrm{G}$ have been described in references cited in ref 5. BSA and HSA are the products of Nakarai Chemicals, Ltd. and Midori Juji, respectively. PLGA and PLL are products of Sigma and their molecular weights are $15000-50000$ and $15000-30000$, respectively. The solution of the membrane-forming surfactants was prepared by sonicating the solution with Bransonic Sonifier 185 for $5 \mathrm{~min}$ in an ice-bath. All the spectral measurements were conducted at $30^{\circ} \mathrm{C}$ by using following apparatus: absorption spectra, Hitachi 200; optical rotation, JASCO DIP-4; circular dichronism, JASCO J-40AS. The spectra of PLGA and PLL were measured at about $\mathrm{pH} 4.1(0.005 \mathrm{M}$ acetate) and 10.8 ( $0.005 \mathrm{M}$ carbonate), respectively. The details are recorded under each table and figure.

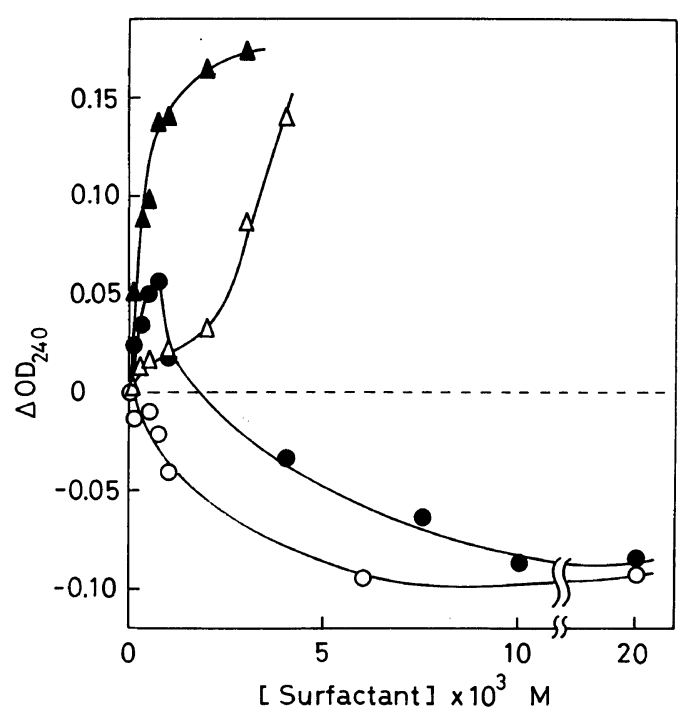

Figure 1. Influence of $\mathrm{SDS}$ and $2 \mathrm{C}_{10} \mathrm{SO}_{3} \mathrm{Na}$ on the difference spectra of bovine serum albumin (BSA) and human serum albumin (HSA). [BSA $]=[\mathrm{HSA}]=0.35$ wt $\%, p H=6.1$ with $0.005 \mathrm{M}$ phosphate buffer.

$\mathrm{BSA}+\mathrm{SDS} ; \mathrm{O}, \mathrm{HSA}+\mathrm{SDS} ; \triangle, \mathrm{BSA}+2 \mathrm{C}_{10} \mathrm{SO}_{3} \mathrm{Na} ; \triangle$, $\mathrm{HSA}+2 \mathrm{C}_{10} \mathrm{SO}_{3} \mathrm{Na}$.

\section{RESULTS}

\section{Denaturation of Albumins}

The surfactant-induced conformational change in albumins can be conveniently monitored by ultraviolet difference spectroscopy. ${ }^{7-10}$ The addition of SDS to the albumin solution induces a conformational change, which is reflected, for example, by the negative difference spectra in the ultraviolet

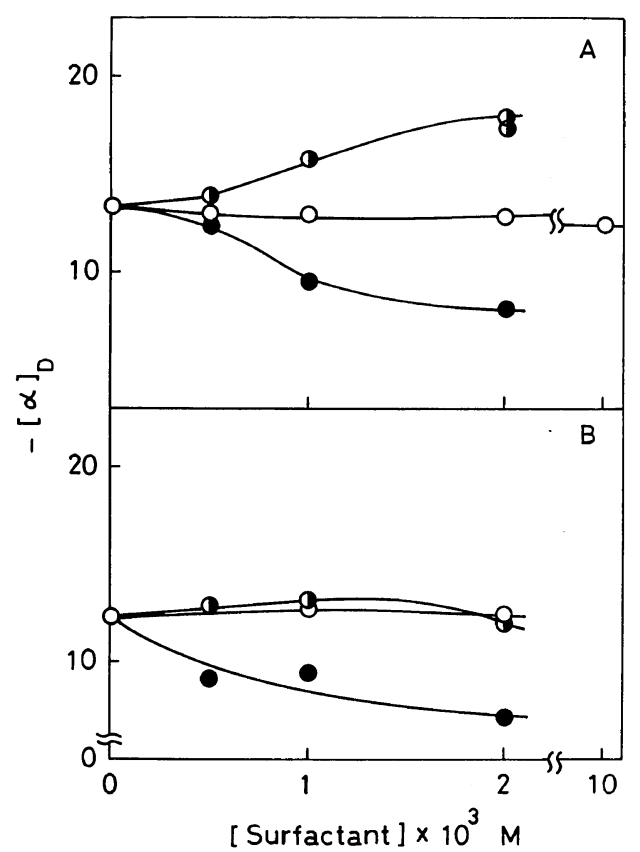

Figure 2. $[\alpha]_{D}$ of poly(L-glutamic acid) (PLGA) as a function of the concentration of surfactants. $[\mathrm{PLGA}]=0.210 \mathrm{~g} \mathrm{dl}^{-1}, l=1 \mathrm{dm}, \mathrm{pH} 4.04$ with $0.005 \mathrm{M}$ acetate buffer. (A): $\bigcirc$, SDS;, PLGA was added to the sonicated solubion of $2 \mathrm{C}_{10} \mathrm{SO}_{3} \mathrm{Na}$; $\mathrm{O}$, the solution was sonicated after mixing PLGA with $2 \mathrm{C}_{10} \mathrm{SO}_{3} \mathrm{Na}$. (B): $\bigcirc$, Brij-35; , PLGA was added to the sonicated solution of $2 \mathrm{C}_{12} 28 \mathrm{G}$; 1 , the solution was sonicated after mixing PLGA with $2 \mathrm{C}_{12} 28 \mathrm{G}$.

Table I. $[\theta]_{222}$ of $\mathrm{PLGA}^{\mathrm{a}}$

\begin{tabular}{lc}
\multicolumn{1}{c}{ Surfactant } & {$[\theta]_{222} \times 10^{-4}$} \\
\hline None & -2.60 \\
$\mathrm{SDS}(10 \mathrm{mM})$ & -2.59 \\
$2 \mathrm{C}_{10} \mathrm{SO}_{3} \mathrm{Na}(2.0 \mathrm{mM})^{\mathrm{b}}$ & -2.79 \\
\hline
\end{tabular}

${ }^{\mathrm{a}}[\mathrm{PLGA}]=0.448 \mathrm{~g}^{-1}, \mathrm{pH} 4.1$.

b PLGA was added to the sonicated solution of $2 \mathrm{C}_{10} \mathrm{SO}_{3} \mathrm{Na}$. 
region. ${ }^{7}$ As shown in Figure 1, the OD value at $240 \mathrm{~nm}$ in the difference spectra decreased with increasing SDS concentration, although the plot for BSA is somewhat complicated at low concentrations. On the other hand, when the $2 \mathrm{C}_{10} \mathrm{SO}_{3} \mathrm{Na}$ solution sonicated in advance was added, the difference spectra took on very different shapes. The OD values increased with increasing $2 \mathrm{C}_{10} \mathrm{SO}_{3} \mathrm{Na}$ concentration, and that of BSA was particularly sensitive to concentration change. It is not easy to speculate the details involved in the conformational change in albumins only on the basis of spectral data. ${ }^{7-10}$ The present results however show clearly that the chromophores of the albumins denaturated by $2 \mathrm{C}_{10} \mathrm{SO}_{3} \mathrm{Na}$ reside in an environment quite different from that denaturated by SDS.

\section{Influence on Poly(amino acid)s Conformation}

The helical content of PLGA can be conveniently estimated by measurement of optical rotation at $589 \mathrm{~nm}\left([\alpha]_{D}\right){ }^{11,12}$ In Figure $2 A$, the $[\alpha]_{D}$ of PLGA is plotted as a function of SDS and $2 \mathrm{C}_{10} \mathrm{SO}_{3} \mathrm{Na}$. The $[\alpha]_{D}$ was almost constant at various SDS concentrations $(-13.1 \pm 0.6$ up to $10 \mathrm{mM})$, whereas the $[\alpha]_{D}$ increased with increasing concentrations of $2 \mathrm{C}_{10} \mathrm{SO}_{3} \mathrm{Na}$ (sonicated in advance). The increase in helical content by adding $2 \mathrm{C}_{10} \mathrm{SO}_{3} \mathrm{Na}$ was also confirmed by the measurement of circular dichroism (CD) (Table I). Based on the $[\theta]$ at $222 \mathrm{~nm}$, we estimated that the helical content increases by $7.3 \%$. According to Imahori and Tanaka, ${ }^{11}$ the $[\alpha]_{\mathrm{D}}$ at zero-helical content is -80 and that at $71 \%$ helical content is -14.8 . We thus estimate that the increment of the $[\alpha]_{D}$ by $5.2(-13.3 \rightarrow-8.1$ : Table II) corresponds to an increase of $5.7 \%$ in helical content. The two values determined by the independent methods are in good accord within experimental error. We thus used the optical rotation for the following measurement.

Interestingly, when the solution was sonicated after mixing PLGA and $2 \mathrm{C}_{10} \mathrm{SO}_{3} \mathrm{Na}$ in a buffer solution, the helical content decreased by $5.0 \%$ (Figure 2A). The contrasting influence of $2 \mathrm{C}_{10} \mathrm{SO}_{3} \mathrm{Na}$ implies that the surfactant membrane "stabilizes" the helical structure, while adding $2 \mathrm{C}_{10} \mathrm{SO}_{3} \mathrm{Na}$ rather "breaks" the helical structure when the membrane-organization was conducted in the presence of PLGA. It should be emphasized that this change in the helical content is seen only for membrane-forming $2 \mathrm{C}_{10} \mathrm{SO}_{3} \mathrm{Na}$ and not for micelle-

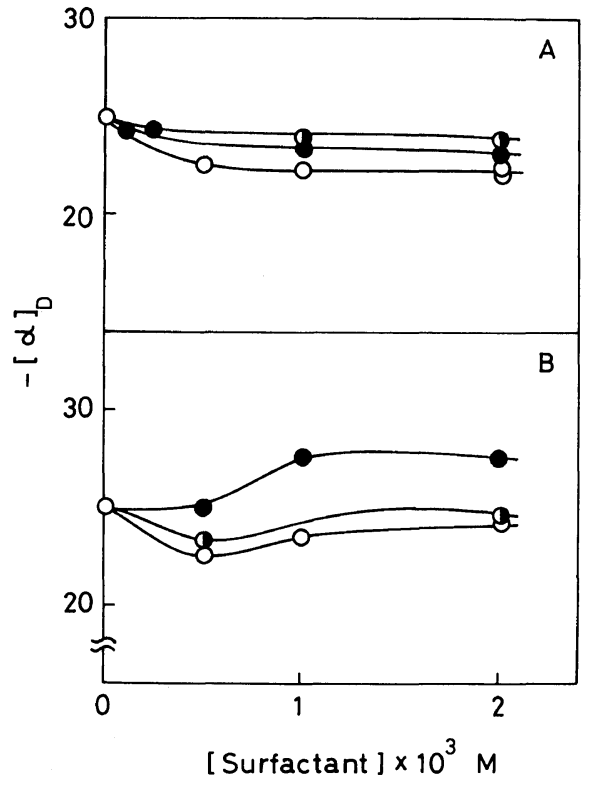

Figure 3. $[\alpha]_{D}$ of poly(L-lysine) (PLL) as a function of the concentration of surfactants. $[\mathrm{PLL}]=0.120 \mathrm{~g} \mathrm{dl}^{-1}$, $l=1 \mathrm{dm}, \mathrm{pH} 10.8$ with $0.005 \mathrm{M}$ carbonate buffer. (A): $\bigcirc$, CTAB; PLL was added to the sonicated solution of $2 \mathrm{C}_{12} \mathrm{~N} 2 \mathrm{C}$; $O$, the solution was sonicated after mixing PLL with $2 \mathrm{C}_{12} \mathrm{~N} 2 \mathrm{C}$. (B): $\bigcirc$, Brij-35;, PLL was added to the sonicated solution of $2 \mathrm{C}_{12} 28 \mathrm{G}$; $O$, the solution was sonicated after mixing $\mathrm{PLL}$ with $2 \mathrm{C}_{12} 28 \mathrm{G}$.

forming SDS. A sonicated solution of $2 \mathrm{C}_{12} 28 \mathrm{G}$ similarly enhanced the helical content, but the helical content was less affected by sonicating $2 \mathrm{C}_{12} 28 \mathrm{G}$ and PLGA (Figure 2B).

The optical rotation of PLL was measured as a function of cationic and nonionic surfactants (Figure 3). With this combination, however, both the micelle-forming surfactants (CTAB and Brij-35) and the membrane-forming surfactants $\left(2 \mathrm{C}_{12} \mathrm{~N} 2 \mathrm{C}\right.$ and $\left.2 \mathrm{C}_{12} 28 \mathrm{G}\right)$ induced a lesser change in the $[\alpha]_{D}$ value. Among the surfactants, the sonicated solution of $2 \mathrm{C}_{12} 28 \mathrm{G}$ was the most efficient additive.

\section{Time-Dependence}

It was noticed that the helical content of PLGA increased gradually over a long period of time. ${ }^{13} \mathrm{We}$ thus examined the time-dependence of the $[\alpha]_{D}$ in the PLGA $+2 \mathrm{C}_{10} \mathrm{SO}_{3} \mathrm{Na}$ system (Figure 4). Typical data are summarized in Table II. The $[\alpha]_{D}$ value of PLGA in an aqueous solution and PLGA in the SDS micelle plotted as a function of time decreased 


\section{S. SHINKAI et al.}

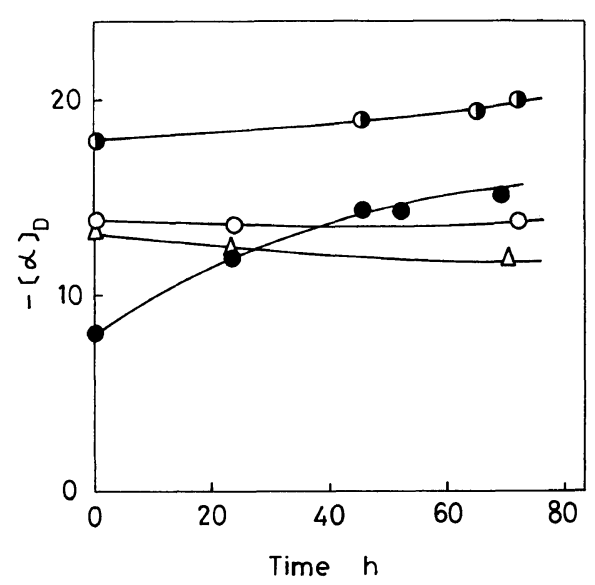

Figure 4. Time dependence of $[\alpha]_{D}$ of PLGA. $\triangle$, no additive; $\bigcirc, \operatorname{SDS}(2.0 \mathrm{mM})$;, PLGA was added to the sonicated solution of $2 \mathrm{C}_{10} \mathrm{SO}_{3} \mathrm{Na}(2.0 \mathrm{mM}) ; \mathrm{O}$, the solution was sonicated after mixing PLGA with $2 \mathrm{C}_{10} \mathrm{SO}_{3} \mathrm{Na}(2.0 \mathrm{mM})$.

Table II. $[\alpha]_{\mathrm{D}}$ of PLGA at $\mathrm{pH} 4.1$

\begin{tabular}{|c|c|c|}
\hline \multirow[t]{2}{*}{ Surfactant (mM) } & $\begin{array}{l}\text { Measurement time } \\
\text { after mixing }\end{array}$ & \multirow[t]{2}{*}[\alpha]{$_{\mathrm{D}}$} \\
\hline & $\mathrm{h}$ & \\
\hline \multirow[t]{2}{*}{ Water } & 0 & -13.3 \\
\hline & 70.5 & -11.9 \\
\hline \multirow[t]{2}{*}{$\operatorname{SDS}(2.0)$} & 0 & -13.8 \\
\hline & 72 & -13.8 \\
\hline \multirow[t]{2}{*}{$2 \mathrm{C}_{10} \mathrm{SO}_{3} \mathrm{Na}(2.0)^{\mathrm{a}}$} & 0 & -8.1 \\
\hline & 69 & -15.2 \\
\hline \multirow[t]{2}{*}{$2 \mathrm{C}_{10} \mathrm{SO}_{3} \mathrm{Na}(2.0)^{\mathrm{b}}$} & 0 & -17.9 \\
\hline & 72 & -20.0 \\
\hline
\end{tabular}

a PLGA was added to the sonicated solution of $2 \mathrm{C}_{10} \mathrm{SO}_{3} \mathrm{Na}$.

b The solution was sonicated after mixing PLGA with $2 \mathrm{C}_{10} \mathrm{SO}_{3} \mathrm{Na}$.

gradually, indicating that the helical content may increase with time. The solution in which PLGA and $2 \mathrm{C}_{10} \mathrm{SO}_{3} \mathrm{Na}$ were sonicated together caused a gradual increase in $[\alpha]_{D}$. Most importantly, the PLGA solution mixed with the sonicated solution of $2 \mathrm{C}_{10} \mathrm{SO}_{3} \mathrm{Na}$, in which the helical content significantly increased immediately after mixing, provided a relatively rapid increase in $[\alpha]_{\mathrm{D}}$, exceeding that of the PLGA solution at $26 \mathrm{~h}$. After $69 \mathrm{~h}, 7.7 \%$ of the helix was destroyed. Thus, it seems that the helix-forming effect of the $2 \mathrm{C}_{10} \mathrm{SO}_{3} \mathrm{Na}$ membrane is temporary and that the thermodynamically-stable random coil gradually increases in the presence of the $2 \mathrm{C}_{10} \mathrm{SO}_{3} \mathrm{Na}$ membrane.

\section{DISCUSSION}

In the denaturation of albumins, it was shown that the difference spectra (positive change) induced by adding $2 \mathrm{C}_{10} \mathrm{SO}_{3} \mathrm{Na}$ are essentially different from those (negative change) induced by SDS. Steinhardt et al. ${ }^{8}$ have examined the influence of various alkyl sulfates on the ultraviolet difference spectra of BSA and HSA. Although subtle spectral perturbations could be observed depending on the length of the alkyl chain, broad resemblance in certain features still remained. As shown in Figure 1, there is no resemblance in the effect of SDS and $2 \mathrm{C}_{10} \mathrm{SO}_{3} \mathrm{Na}$ on $\triangle \mathrm{OD}$ of the difference spectra. The contrasting behavior of these two surfactants cannot be rationalized in terms of the difference in their hydrophobicity. Instead, the difference in their aggregation modes should be taken into consideration.

The spectral changes in albumins may be explained in two ways: on the denaturation, (i) the chromophores move to a different environment in the albumin or (ii) the chromophores interact directly with the surfactant molecules, reflecting the environment of the surfactant aggregates. In denaturation by SDS, it is recognized on the basis of a shift of the difference spectra at the high-energy transition $(\sim 230 \mathrm{~nm})$ that some of the chromophores were originally in content with solvent water and when SDS molecules are bound to the albumins, they shield the chromophores from this aqueous contact. ${ }^{8,14}$ Thus, the more probable explanation is (ii). Since $2 \mathrm{C}_{10} \mathrm{SO}_{3} \mathrm{Na}$ provided an opposite influence on the difference spectra, it may be said that denaturation occurs in such a way that some of the chromophores may come in contact with water more easily. Hence, the $2 \mathrm{C}_{10} \mathrm{SO}_{3} \mathrm{Na}$ membrane is not capable of shielding the chromophores from the aqueous contact.

The influence of micelle-forming surfactants and phospholipid membranes on the conformation of polypeptides and poly(amino acid)s has been reported by several groups. ${ }^{2-4,15-18}$ But there has been no systematic investigation to determine whether the influence of the surfactant aggregates 
with the membrane structure is different from that of the micellar aggregate. We found that the mode of interaction of membrane-forming surfactants is quite different, although not without exception, from that of the micelle-forming surfactants. The clearest difference is seen in the combination of PLGA and anionic surfactants. In contrast to the lack of influence of SDS on the helical content, the influence of $2 \mathrm{C}_{10} \mathrm{SO}_{3} \mathrm{Na}$ was quite distinct and depended on the treatment procedure. The helix is a higher-order structure of polymeric PLGA, and the membrane is also a sort of assembly structure of amphiphiles. When these two structures are mixed, the initial interaction leads to an increase in the helical content. With time, the two structures would probably fuse with each other, leading to a gradual decrease in helical content. This fusion can be rapidly achieved by sonicating the solution containing both $2 \mathrm{C}_{10} \mathrm{SO}_{3} \mathrm{Na}$ and PLGA, attaining the thermodynamically-stable helical content. It is not clear at present as to what type of interaction is important between $2 \mathrm{C}_{10} \mathrm{SO}_{3} \mathrm{Na}$ and PLGA. This question may be possibly clarified by using membrane-forming surfactants of different hydrophobicity and/or by introducing certain hydrophobic substituents into PLGA.

In conclusion, the present study has demonstrated that the membrane-forming surfactants developed by Kunitake ${ }^{5}$ cause behavior patterns quite different from the micelle-forming surfactants in interactions with albumins and poly(amino acid)s. This is important for understanding the relationship between biomembranes and membrane-bound proteins. An investigation is currently being carried out in these laboratories.

Acknowledgment. S. S. should like to express its appreciation to the Ministry of Education, Science and Culture of Japan for Grant-in-Aid for Scientific Research (No. 555365).

\section{REFERENCES}

1. W. W. Sukow, H. E. Sandherg, E. A. Lewis, D. J. Eatough, and L. D. Hansen, Biochemistry, 19, 912 (1980) and references cited therein.

2. I. Satake and J. T. Yang, Biochem. Biophys. Res. Commun., 54, 930 (1973).

3. K. Shirahama and J. T. Yang, Int. J. Peptide Protein Res., 13, 341 (1979).

4. C.-S. C. Wu and J. T. Yang, Biochemistry, 19, 2117 (1980).

5. T. Kunitake, Maku (Membrane), 4, 166 (1979); J. Macromol. Sci., Chem., A13, 587 (1979).

6. J. H. Fendler, Acc. Chem. Res., 13, 7 (1980).

7. C. C. Bigelow and M. Sonenberg, Biochemistry, 1, 197 (1962)

8. J. Steinhardt, J. G. Leidy, and J. P. Mooney, Biochemistry, 11, 1809 (1972).

9. M. J. Pallansch and D. R. Briggs, J. Am. Chem. Soc., 76, 1396 (1954).

10. R. V. Decker and J. F. Foster, Biochemistry, 5, 1242 (1966).

11. K. Imahori and J. Tanaka, J. Mol. Biol., 1, 359 (1959).

12. J. Applequist and J. J. Breslow, J. Am. Chem. Soc., 85, 2869 (1963).

13. M. Morcelle and C. Loucheux, Eur. Polym. J., 14, 679 (1978)

14. J. Steinhardt and J. A. Reynolds, "Multiple Equilibria in Porteins," Academic Press, New York, N. Y., 1969

15. I. Satake and J. T. Yang, Biopolymers, 14, 1841 (1975).

16. D. J. Kroon, J. P. Kupferberg, E. T. Kaiser, and F. J. Kezdy, J. Am. Chem. Soc., 100, 5975 (1978).

17. T. Yamashita, A. Shibata, and S. Yamashita, Bull. Chem. Soc. Jpn., 51, 2751 (1978).

18. A. Shibata, S. Yamashita, and T. Yamashita, Bull. Chem. Soc. Jpn., 51, 2757 (1978). 